\title{
Yrittäjän muotokuva - persoonallisuus, taitaminen ja tilannetekijät yhdessä
}

\author{
Soili Keskinen \& Nana Virtanen
}

\begin{abstract}
Millä tavalla tilannetekijät säätelevät ryhtymistä yrittäjäksi? Millainen ihminen ryhtyy yrittäjäksi? Millaisia ominaisuuksia yrittäjältä vaaditaan? Millainen on persoonallisuudeltaan tyypillinen yrittäjä vai onko sellaista? Tämän kirjallisuuden pohjalta tehdyn katsauksen tarkoituksena on vastata näihin kysymyksiin käyttäytymistieteellisestä näkökulmasta. (Ks. myös Virtanen \& Keskinen 2000).
\end{abstract}

Vanhimman tunnetun määritelmän yrittäjyydestä on esittänyt ranskalainen talousmies Richard Cantillon 1750-luvulla. Hänen määritelmänsä mukaan yrittäjä on kaukonäköinen, taitava ja määrätietoinen henkilö, joka on voittoa saadakseen valmis turvautumaan suuriin riskinalaisiin hankkeisiin. Cantillonia voidaan pitää eritoten varhaisena maatalousyrittäjyyden määrittelijänä. (Lahti 1989, 28, Kinkki 1992, 164.) Jo tämä pari sataa vuotta vanha määrittely yrittäjyydestä sisältää yhdistelmän tietynlaisista persoonallisuudenpiirteistä, esimerkiksi määrätietoisuudesta, taidon tasosta ja sopivan tilanteen, hankkeen olemassaolosta. Uudemmassa ja kotimaisessa yrittäjyyden määrittelyssä korostuu yrittäjyys toiminta-, ajattelu- ja suhtautumistapana, joka saa henkilön ottamaan kokonaisvastuuta tavoitteiden saavuttamiseksi, ottamaan riskejä ja toimimaan oman sisäisen mielikuvan ja vision ohjaamana (esim. Huuskonen 1992, Jokela \& Anneberg 1995).

Yrittäjyystutkimuksessa yleisimmin käytetyt näkökulmat ovat taloustieteellinen, psykologinen ja sosiologinen näkökulma (Mäkinen 1977, Aldrich \& Zimmer 1986, Pitkänen \& Vesala 1988). Tässä kirjallisuuskatsauksessa yrittäjyyttä käsitellään kasvatustieteellis-psykologisena ilmiönä. Yrittäjänä toimimisen motiivien analysoiminen antaa viitteitä siitä, miten yrittäjille pitäisi järjestää koulutusta, miten yrittäjänä oppimista voisi aktivoida ja yrittäjänä kehittymistä tukea.

\section{Tilannetekijät yrittäjäksi ryht ymisessä}

Tilannetekijöillä tarkoitetaan sitä välitöntä "reaalista" ympäristöä, jossa yrittäjyyttä harkitseva ihminen elää ja toimii. Yrittämisympäristön tarkastelussa voidaan erottaa lisäksi subjektiivinen todellisuus. Suhteessa yrittäjyyteen tilannetekijät jakautuvat kahteen leiriin, nimittäin myönteisiin eli ns. vetäviin ja kielteisiin eli työntäviin tekijöihin. Ne voivat johtua joko sisäisistä henkisistä tiloista tai ulkoisista olosuhteista. Myönteiset vetävät syyt ovat niitä toivottuja seikkoja, joita ei olisi ollut mahdollista saavuttaa ryhtymättä yrittäjäksi. Yrittäjäksi vetävät eri syyt eri 
maissa. Hyvin usein toistuvat "halu itsenäisyyteen ja riippumattomuuteen" ja muut itsensä toteuttamiseen liittyvät seikat. Myönteisiä, yrittäjyyteen vetäviä tekijöitä on havaittu olevan myös mm. yhteiskunnan luomat edellytykset yritystoiminnalle. Tällaisia edellytyksiä ovat $\mathrm{mm}$. henkinen ja rahallinen tuki (starttiraha, julkiset neuvonta- ja koulutuspalvelut), yrityshautomot ja teknologiakylät. Lisäksi vallitseva asenneilmasto yrittäjyyttä kohtaan vaikuttaa yrittäjyyteen vetävästi. Tämän lisäksi luonnollisesti vastaantuleva "miljoonan markan" tilaisuus, houkutteleva yritysidea kuuluu yrittäjyyteen vetävien tekijöiden joukkoon. Kielteisinä, lähtöorganisaatiosta kohti yrittäjyyttä työntävinä tekijöinä pidetään kirjallisuudessa tavallisimmin työttömyyttä ja työttömyyden uhkaa, viihtymättömyyttä nykyisessä tehtävässä, etenemismahdollisuuksien puutetta, sosiaalista marginaalisuutta sekä huonoa sopeutumista alaiseksi.

$\mathrm{P}_{\mathrm{n}}$ äätökselle lähteä yrittäjäksi antaa usein kimmokkeen joku erityinen tapahtuma, joka murtaa pidäkkeet entiseen. Ratkaisevana tekijänä voi olla riita työpaikalla, ikäkausikriisi tai muu henkinen murros. Myös positiiviset seikat voivat vaikuttaa tällä tavalla. Vallitseva asenneilmasto yrittäjyyttä kohtaan vaikuttaa myös subjektiivisen tason päätöksiin. Jos omaiset ja tuttavat suhtautuvat yrittäjyyteen kielteisesti ja epäillen, se vaikuttaa todennäköisesti sitä harkitsevan ajatuksiin. Yritystoiminta voidaan aloittaa hyvin eri tavoin: perustamalla, ostamalla tai perimällä (sukupolvenvaihdos). Yrityksen toiminnallinen taso ja "valmiusaste" vaikuttavat aloittamispäätöksen helppouteen. Voidaan olettaa, että jo vakiintuneen ja tutun yrityksen haltuunotto on henkisesti helpompaa kuin tyhjästä aloittaminen. (Huuskonen 1992, 184-185, Sutinen 1994, 26.) Yrittäjäksi ryhtymisen taustalla voi olla myös työttömyyden uhka (mm. Niittykangas 1985, 132133, Littunen 1989 ja 1992, Niittykangas \& Tervo 1993, 48), oman erityisosaamisen hyödyntäminen oman yritystoiminnan kautta tai uralla eteneminen yritystoiminnan kautta $(\mathrm{mm}$. Stanworth \& Curran 1973). Yrityksen perustaminen voi myös mahdollistaa sosiaalisen liikkuvuuden niin, ettei esimerkiksi koulutuksen puute tai vähäisyys luo ylitsepääsemätöntä estettä työelämässä etenemiselle tai ammattiuralle. (Turunen \& Niemelä 1995, 21.)

Yrittäjäksi ryhtyminen saattaa hyvinkin perustua siihen, että yrittäjäksi ryhtynyt henkilö ei nähnyt mielestään muita yhtä hyviä vaihtoehtoja ja siksi päätyi yrittäjäksi. Toisin sanoen hänen subjektiivisessa todellisuudessaan ei ollut muita yhtä hyviä vaihtoehtoja, joten niistä paras tuli valituksi. Se, minkälaiset liiketoimintatilaisuudet ja mahdollisuudet tosiasiassa ovat, ei ole yrittäjäksi ryhtymisen kannalta ratkaisevaa, vaan se, minkälainen subjektiivinen arvio ja johtopäätös niistä tehdään. (Huuskonen 1992, 185.)

$A_{\text {ikomus ryhtyä yrittäjäksi syntyy, jos haluttu }}^{\text {ikäyttää riittävän houkuttelevalta sen }}$ vaatimiin ponnistuksiin ja "uhrauksiin" nähden. Aikomusta ryhtyä yrittäjäksi ei synny, jos toiminnan arvioidut panokset ovat liian suuret odotettaviin tuloksiin nähden. Eteneminen kohti uutta yritystä ei ole suoraviivaista tai tasavauhtista. Suunnitelmat saattavat olla eri syistä pitkän ajan pysähdyksissä. Myös olosuhteiden odottamattomat muutokset saattavat palauttaa yrittäjäksi ryhtymisen takaisin prosessin aiempaan vaiheeseen tai lopettaa sen suunnittelun pysyvästi. Luopumista hankkeesta voi tapahtua sen kaikissa vaiheissa. Yrittäjäksi ryhtyminen ei ole suoranaista seurausta tilanteista, henkilön ominaisuuksista, sosiaalisesta tilanteesta tai mistään muustakaan yksittäisestä seikasta. Eri tausta-, henkilö- ja tilannetekijät vaikuttavat monimutkaisena prosessina toisiinsa. Jotkut tekijöiden yhdistelmät luovat yrittäjämyönteisiä tulkintoja ja näkemyksiä, ja siten tekevät yrittäjäksi ryhtymisen todennäköiseksi. (Huuskonen 1992, 186-187.)

Yrittäjäksi ryhtymistä säätelevät monimutkaisella tavalla tilannetekijät ja persoonallisuus. Subjektiivinen tulkinta yrittämiselle otollisten olosuhteiden havaitsemiseksi on olennaista. Subjektiivinen tulkintatapa taas puolestaan on sidoksissa persoonalliseen toiminta- ja ajattelutapaan, henkilökohtaisiin visioihin ja elämänarvoihin. Ts. yrittäjäksi ryhtymiseksi ei riitä, että objektiivisesti arvioiden olisi olemassa otollinen hetki tai tilanne tai sosiaalinen tilaus yrittäjyydelle. Tarvitaan lisäksi persoonallisuuden kautta syntyvä 
subjektiivinen varmuus yrittäjäksi ryhtymisen mielekkyydestä ja motivoivuudesta.

\section{Mitä persoonallisuus- ominaisuuksia tarvitaan?}

"Ihmiset aina moittivat olosuhteita ja ympäristöä. Minä en usko olosuhteisiin. Pystyvät ihmiset tässä maailmassa ovat niitä, jotka etsivät toiminnalleen oikeita olosuhteita, mutta elleivät löydä, tekevät ne" (Shaw)

$\mathrm{T}$ eemaa "menestyvän yrittäjän persoonallisuus" on käsitelty maamme oppikirjoissa jo tsaarinajoista lähtien. Lainataksemme kahta suomalaislähdettä (Laitinen 1985, 216) vuonna 1882 Scheutz kirjoitti oppaan "Käytännöllinen kauppamies. Käsikirja kauppiaille ja käsityöläisille sekä nuorukaisille, jotka aikovat astua elinkeinoluokkiin”. Scheutz jakoi hyvän yrittäjän ominaisuudet fyysisiin ja henkisiin. Yrittäjiltä vaaditaan hyvää terveyttä ja kestävyyttä. Henkisistä ominaisuuksista ovat keskeisiä tarkka pää ja nopea käsityskyky. Lisäksi vaaditaan annos ahkeruutta ja intoa. Erityisinä muina vaatimuksina Scheutz listaa järjestelykyvyn, hyvän maun, kekseliäisyyden ja keinottelevaisuuden. Kolmetoista vuotta myöhemmin Helander julkaisi teoksen "Oppikirja kansantaloudessa. Kauppakouluja varten". Hän totesi, että yrittäjältä (Helander: "tehtailijalta”) vaaditaan järjestely-, arvostelu- ja johtamiskykyä sekä uskallusta ottaa riski yrityksen onnistumisesta. Scheutzin määrittelyssä yrittäjäpersoonallisuudesta korostuu näkemys taitamisesta, osaamisesta, Scheutzin termein "keinottelevaisuudesta".

\section{Tarvitaan ekstroverttiyttä, internaalisuutta ja korkeata suoritusmotivaatiota}

Yrittäjyys on sekä yksilöllinen että sosiaalinen piirre. Se edellyttää tiettyä motivaatiota, älykkyyttä ja temperamenttia. Motivaation osalta yrittäjän täytyy olla orientoitunut avautuviin mahdollisuuksiin, markkinoiden muutoksiin ja kilpailuun. Hänellä täytyy olla sekä suunnitelmallisuutta että rohkeutta riskien ottamiseen, mutta myös valmiutta oppia erehdyksistä. Yrittäjän ei tarvitse olla nero, mutta hänen täytyy pystyä mobilisoimaan älylliset lahjansa yrittämiseen, sellaisen arvoketjun edistämiseen, jossa on asiakkaan edun mukaista jatkaa asiakassuhdetta ja siten vakiinnuttaa yrittäjänkin asemaa. Yrittäjän ei myöskään tarvitse olla temperamentiltaan täysin tasapainoinen ja nopealiikkeinen ekstravertti, mutta hänen täytyy pystyä herättämään luottamusta omassa tiimissään ja verkostonsa asiakkaissa. (Nurmi 1999, 31.) Nurmi käyttää määrittelyssään yrittäjyydestä perinteisiä persoonallisuudenpsykologian käsitteitä: tempperamentti ja ekstroverttiys (ulospäin suuntautuneisuus), mutta myös oppimisen käsitteistöä: yrittäjän on osattava oppia virheistään.

$\mathrm{Y}^{\mathrm{s}}$ rittäjän ja yrittäjyyden ominaispiirteisiin kuuluvat mm. itseluottamus, idearikkaus, usko yrittämiseen, valmius tehdä uhrauksia, päättäväisyys ja riskinottokyky (Järvinen 1986, 10, Laitinen 1986, 8, Peltonen 1986, 20). Usko itsenäisen työn ja omien aikaansaannosten arvoon ihmisen elämässä on yrittäjyyden ydin. Tällöin korostuu yrittäjän persoonallisuuden internaalisuus (taipumus ymmärtää oman toiminnan seuraukset itsestä lähtöisin) ennemminkin kuin eksternaalisuus. Yrittämisen ehdoton edellytys on halu menestyä (Tulkki \& Vakkuri 1996, 5.). Persoonallisuuspsykologian termistöin kyse on korkeasta suoritusmotivaatiosta.

$\mathrm{K}$ asvuhalukkuuden ja oppimiskyvyn ohella myös sitoutuminen yrittäjyyteen on tärkeää. Yrittäjyyden kulmakiviä ovat kyky, halu ja uskallus, jossa uskallus oikeastaan edustaa riskinottohalua ja -kykyä. Henkinen kasvu yrittäjyyteen on näiden tekijöiden vahvistamista. Persoonallisuutemme näkyvät piirteet heijastelevat sekä synnynnäisiä että opittuja ominaisuuksia. Myös yrittäjäpersoonallisuus muotoutuu sekä synnynnäisten että opittujen tekijöiden yhteisvaikutuksesta. (Koiranen 1997, 24.) On kuitenkin mahdotonta, ja merkityksetöntäkin määritellä, missä määrin yrittäjäpersoonallisuus edellyttää synnynnäisiä taipumuksia, missä määrin on mahdollista hyvien olosuhteiden vallitessa kehittyä persoonallisuudeltaan sellaiseksi, että yrittäjänä toimiminen onnistuu. 


\section{Kyky joustaa sekä muutosten ja stressin sieto yrittäjyydessä}

Darkkinen (1999, 63-68) näkee yrittäjän tärkeiksi ominaisuuksiksi aktiivisuuden, kärsivällisyyden, nöyryyden, herkkyyden ja epävarmuuden siedon, heikkojen signaalien aistimisen, ainutlaatuisuuden, henkisen pääoman, luotettavuuden, ammattitaidon sekä sen, että yrittäminen perustuu palveluun. Yrittämisessä kaikki edellytykset ovat johdettavissa siitä tosiasiasta, että yrittäjä on itse kaiken toiminnan moottori. Sen pohjalta voi heti luetella joukon ominaisuuksia: tavoitteellisuus, oma-aloitteisuus, aktiivisuus ja itseluottamus ovat ainakin tarpeen. Pitkäjänteisyyttä, sitkeyttä ja kärsivällisyyttä tarvitaan sen vuoksi, että hyvänkin tuotteen läpivienti markkinoille vaatii aikaa. Yrittäjän on aistittava, mitä ajassa liikkuu kyetäkseen ennakoimaan tulevan kehityksen ja toimimaan silloin, kun on oikea aika.

Kyky sietää epävarmuutta ja jatkuvaa muutosta kuuluu yrittäjänä onnistumisen perusedellytyksiin. Vain siten pystyy aloittamaan aina uuden päivän puhtaalta pöydältä. Parhaimmillaan yrittäjä ei vain siedä muutosta, vaan nauttii siitä ja hän itse johtaa ja vie muutosta eteenpäin muutosagenttina. Kilpailevien tuotteiden uhka on voitettavissa ideaprosessin jatkuvalla käynnissä pitämisellä. Se sisältää dynamiikan, joka pitää yrityksen elävänä. Samalla on kuitenkin luotailtava markkinoita eli asiakkaiden mielenliikkeitä varsin tiivisti. Vaikkei uskoisikaan itse olevansa aivan ylivoimainen, on kuitenkin pyrittävä löytämään omasta ideastaan ja kyvystään sen toteuttamiseksi se ainutlaatuisuus, jota muiden on vaikea jäljittää.

Tietoa ympäröivästä maailmasta on pystyttävä ottamaan kaikkialta ja sulattamaan se omaksi henkiseksi pääomaksi. Näin voi välttää ajastaan jälkeen jäämisen, mikä ennen pitkää johtaa putoamiseen markkinoilta. Yrittäjä joutuu toimimaan niin moniin tahoihin nähden samanaikaisesti, että painetta, stressiä, on pakko oppia sietämään melkoinen määrä. Suhteessa asiakkaisiin hänen on oltava äärimmäisen joustava ja palveluhaluinen, kuitenkin jämerä suhteessa kilpailijoihin, tarvittaessa kovakin, mutta oman henkilöstön kanssa, jos sellaista on, erittäin yhteistyökykyinen, ja suhteessa viranomaisiin vähintään yhtä määrätietoinen ja omanarvontuntoinen kuin nämäkin.

Kansainvälistymisen myötä kielitaidon merkitys on noussut entistä suuremmaksi. Asiakkaan luottamusta ei voi saavuttaa ilman luotettavuutta. Kontaktit eri tahoille ja sieltä tulevat ristikkäispaineet asettavat yrittäjän johdonmukaisuuden kovalle koetukselle. Tavoitteet ja suunta tulee pitää kirkkaina mielessä. Johdonmukaisuuteen liittyy järjestelmällisyys. On pystyttävä itse panemaan asiat tärkeys- ja aikajärjestykseen. Muuten on edessä nopeasti töiden kasaantumien ja kaaos. Tässä Parkkisen (1999) määrittelyssä yrittäjyydestä nousevat esille ne moninaiset vaatimukset, joita tyypillisesti yrittäjänä onnistumiseen suunnataan. Persoonallisuusnäkökulmasta Parkkisen määrittely tuo esille erityisesti persoonallisuuden tasapainoisuuden, itsetunnon vahvuuden ja stressinsietokyvyn merkityksen.

\section{Yrittäjäpersoonallisuuteen kohdistuvat moninaiset vaatimukset}

$\mathrm{N}$ äsin $(1991,43)$ mukaan voidaan todeta yrittäjän olevan tahtoihminen, toimintahakuinen, tuloksiin pyrkivä, näkijä, verkkojen rakentaja, valmentaja, jämäkkä ja asialleen omistautuva. Kostenbaumin (1993, 50-51) mukaan keskeistä johtajuudessa ja yrittäjyydessä on neljän asian tasapaino. Yksi on eettinen ulottuvuus: etiikka mm. muistuttaa, etteivät kaikki keinot ole sallittuja. Toinen on visionäärisyys, älyllinen kirkkaus nähdä ja ajatella suuresti. Kolmas on realismi, joka merkitsee kykyä tosiasioiden oivaltamiseen ja tunnustamiseen. Neljäs on rohkeus, joka ilmenee voimana, uskalluksena ja aloitteellisuutena. Myös Metcalf (sit. Peltonen 1993, 43.) painottaa yrittäjän oma-aloitteellisuutta. Yrittäjällä on oltava kyky johtaa, organisoida ja ottaa vastuutta. Päätöksentekijänä hänen tulee olla jahkailematon. Menestyvällä yrittäjällä yhdistyvät tekninen tietämys, viestintäkyvyt, ihmissuhdekyvyt, yleinen henkinen kyvykkyys sekä yritte- 
liäisyys. (Pickle \& Abrahamsson 1976.) Peltosen (1986, 87-88) mukaan yrittäjäpersoonallisuutta hallitsee neljä perusulottuvuutta, joita ovat ns. yrittäjäkyvyt, perinteisten arvojen korostaminen, kiinnostus rahan hankkimiseen sekä kilpailuhalu.

On joukko ominaisuuksia, jotka on todettu positiivisiksi ja menestyksen varmistajiksi yrittäjän ammatissa. Tällaisia ominaisuuksia ovat esimerkiksi luovuus, kyky visioida tulevaisuutta ja kehitystä, itsenäisyys, päättäväisyys, päätöksentekokyky, itseluottamus ja usko omiin kykyihin ja mahdollisuuksiin, riskinottokyky ja -halu, aloitekykyisyys, tavoitteellisuus ja tarmokkuus, halu saada aikaan tuloksia ja panostaa niiden saavuttamiseen, taito motivoida ja saada muut henkilöt yrityksessä mukaan innovatiiviseen ja tehokkaaseen toimintaan, ulospäinsuuntautuneisuus, kommunikointikykyisyys ja vakuuttavuus, kyky ja halu oppia omista kokemuksista ja epäonnistumisista, tahto olla kilpailijoitaan osaavampi ja tehokkaampi, olla valmis kovaankin kilpailuun, halu oppia jatkuvasti uutta eikä pitäytyä vanhaan, organisointikyky, kyky käyttää muiden asiantuntemusta hyväksi yritystoiminnassa, nähdä yhteistyö mahdollisuutena, kyky tukea ja kannustaa henkilöstöä, oivallus siitä, että muidenkin menestyminen antaa mahdollisuuden myös itselle ja omalle yritykselle. Luettelossa on kuvattu niitä ominaisuuksia, jotka ovat tyypillisiä menestyvälle yrittäjälle. Kenelläkään ei ole niitä kaikkia. Luettelo on pikemminkin tavoitekehikko. Jokainen voi pyrkiä kehittämään omaa osaamistaan ja yrittäjäpersoonallisuuttaan. Usein tällaisia ominaisuusluetteloita on kritisoitu siksi, että ne on tulkittu vaatimuslistoiksi ominaisuuksista, joita ilman ei yrittäjänä menestyisi. Näinhän asia ei ole, vaan kenelläkään tuskin on näitä kaikkia lueteltuja ominaisuuksia. (Jokela \& Anneberg 1995, 50.)

\section{Riskinottohalu yrittäjäpersoonan}

\section{osana}

$Y_{k}$ rittäjäksi ryhtyvällä on oltava kykyä ja halua kestää ja käsitellä riskejä. Riskit voivat olla todellisia tai kuviteltuja. Kuvitellut riskit eivät ole sen vaarattomampia kuin todellisetkaan. Kuviteltujen riskien aiheuttamat pelot voivat päin- vastoin olla paljon lamaannuttavampia, koska niitä on vaikeampi järkiperäisesti analysoida ja ratkaista. Tutkimusten mukaan yrittäjäväestö ei kuitenkaan olennaisesti poikkea valtaväestöstä riskien suhteen; riskejä otetaan pakosta eikä rakkaudesta niihin. Yrittäjäksi aikovan ei siis tarvitse olla tyypiltään peloton riskiottaja, vaan riskinottokyky on opittava ominaisuus, joka kasvaa yrittäjyyden mukana. Riskinottokyky liittyy optimistiseen asenteeseen ja perusluottamukseen siitä, että asiat voidaan aina ratkaista tavalla tai toisella. (Lehtipuro ym. 1999, 159.) Yrittäjyyden tunnuspiirteitä ovat vastuun ja riskien ottaminen. Vastuu asiakkaan tyytyväisyydestä sopii - jo laatusyistä - hyvin koko työyhteisön ajattelun ja toiminnan läpäisyperiaatteeksi. Riskien ottaminen on tyypillisesti optimoitava, mutta ei maksimoitava asia. Varmuus on voiton vihollinen, mutta holtiton riskinotto on väärää yltiöpäisyyttä. Luovuus ja kekseliäisyys, jotka aina sisältävät riskejä, ovat innovatiivisuuden siemeniä, ja innovatiivisuus puolestaan on yrittäjyyden keskeinen ominaispiirre uutteruuden ohella. (Koiranen \& Tuunanen 1996, 15.)

Epävarmuuden sietokyky liittyy riskinottokykyyn. Alkavan yrittäjän ei kuitenkaan ole syytä vaipua epätoivoon, vaikka epävarmuuden sietokyky olisi aluksi hyvinkin alhainen: se kasvaa itsestään yrittäjyysprosessin edetessä. Yrittäjälle jatkuva muutos ja epävarmuus on arkipäivää ja pian se alkaa tuntua luonnolliselta. Yrittäjälle riski ei saa olla pääsääntöisesti negatiivinen käsite. Hallittu riskinotto on yrittäjätoimintaan olennaisesti kuuluva tekijä, joka myös mahdollistaa hyvän tuloksen ja yrityksen kehittymisen. (Lehtipuro ym. 1999, 159-161.)

\section{Päätöksentekotaito on osa yrittäjänä menestymistä}

V alinta/päätöksentekoprosessi on hyvin mut1989, Brunsson 1989, Kast \& Rosenzweig 1970, March \& Olsen 1979). Pystyäkseen tekemään valintoja/päätöksiä tulevaisuutta varten päätöksentekijä tarvitsee tietoa ja kokemusta päätöstä vaativasta asiasta. Tämän johdosta eri yksilöiden valinta/päätöksentekotilanne muodostuu erilaiseksi 
useiden eri tekijöiden vuoksi. Päätöksentekotilanteessa korostuvat sekä päätöksentekijän henkilökohtaiset ominaisuudet että päätöksentekotilanteen olosuhteet. Päätöksentekoprosessin tutkiminen on tärkeää erityisesti pk-yritysten osalta, koska yrittäjä tekee päätökset yleensä yksin. Tällöin valinnan/päätöksen epäonnistumisen seuraamukset ovat merkittäviä koko yrityksen toiminnan jatkumisen kannalta. Yrittäjä ja yritys muodostavat käytännössä yhden kokonaisuuden, jolloin yrittäjän tekemillä päätöksillä on suuret vaikutukset myös yrittäjän perheeseen. Näin yrittäjän tulevaisuuteen suuntautuva päätöksenteko ulottaa vaikututuksensa hyvin laajalle (Palojärvi 1998, 2, Nurmi 1995, 1.)

Inhimillisten tekijöiden merkitys korostuu myös päätöksentekoprosessissa. Siihen sisältyvät tieto, tunne, intuitio, tahto ja uskomukset. Myös suurissa päätöksissä lopullinen valinta/päätöksenteko tapahtui pitkälle inhimillisten tekijöiden, lähinnä tunteen perusteella. Yrittäjät kokevat päätöksentekotilanteessa monenlaisia tunteita. Osa tunteista on myönteisiä, mutta osa on kielteisiä. Tutkimuksen mukaan pk-yrittäjän on aina tunnetasolla vakuututtava siitä, että tehty päätös on rationaalinen. Tällöin tunteilla on merkittävä osuus päätöksentekoprosessissa sillä tavalla, että niiden avulla päätös saadaan aikaiseksi eli tunteiden avulla ylitetään "päätöskynnys". (Palojärvi 1998)

\section{Yrittäjien heterogeenisuus}

$\mathrm{P}_{\mathrm{r}}$ aljon aikaa ja energiaa on uhrattu piirreteoreettisiin selvityksiin siitä, millainen menestyvä yrittäjä on luonteenpiirteiltään. Samoin on tutkittu paljon myös menestyvien johtajien profiilitekijöitä. Saadut tulokset ovat olleet niin ristiriitaisia (Koiranen 1993, 41) ja monenkirjavia, että päällimmäiseksi näyttää jäävän havainto: menestyvillä yrittäjillä on yksi yhteinen piirre, he ovat kaikki erilaisia. Sama, hieman kyyninen näkemys syntyy myös johtajuustutkimuksista: menestyvillä johtajilla on yhteisenä piirteenä erilaisuus (Koiranen \& Peltonen 1995, 79.).

Gartnerin (1985) mukaan yrittäjien joukon sisällä on vaihtelua aivan yhtä paljon kuin yrittäji- en ja ei-yrittäjien välillä. Yrittäjät ovat erittäin heterogeeninen joukko. On siis hyvin epätodennäköistä, että pystyttäisiin kehittämään todella käyttökelpoinen psykologinen profiili, jonka perusteella heidät voitaisiin erottaa muista ihmisistä. Persoonallisuuspiirteet eivät ainakaan yksin näytä riittäviltä yrittäjän tunnusmerkeiltä (Low \& MacMillan 1988, 148). Piirteiden ei myöskään ole todettu erottelevan menestyviä yrittäjiä epäonnistujista (Lorrain \& Dossault 1988, 150-164).

$\mathrm{M}$ otiiveiltaan yrittäjät voivat olla hyvin eriaisia: toisille yrittäjyys (omistajayrittäjyytenä) on ensisijaisesti vakaan toimeentulon lähde ja vasta toissijaisesti, jos lainkaan, kasvutavoitteista. Näille ihmisille yrittäjänä oleminen sinänsä on tärkeämpää kuin yrityksen kasvaminen. Toisille taas kasvu on hyvin keskeistä. Osa on päätynyt yrittäjiksi "vetovoimien" perusteella, toiset "työntövoimien" perusteella. Osa yrittäjistä on silmiinpistävän itsellisiä: yksinyrittäjiä. Toiset hankkiutuvat monin eri sitein vuorovaikutukseen ja käyttävät hyväkseen monia verkostumisen muotoja. Toisilla yrittäjistä on hyvä pitkälle näkemisen taito; he tarttuvat niihin mahdollisuuksiin, jotka kasvavat vuosien työn tuloksista. Toisilla yrittäjyys on sähäkkyyttä ja joustavuutta ajan hermolla, tässä ja nyt -tyyliin. (Koiranen \& Peltonen 1995, 79.) Yrittäjätyyppejä on monia erilaisia, esimerkiksi käsityöläisidentiteetin, klassisen yrittäjäidentiteetin tai toimitusjohtajaidentiteetin omaavat yrittäjät, akateeminen yrittäjä, "self-made-man" -tyyppinen yrittäjä, pakkoyrittäjä jne. (kts. Virtanen \& Keskinen 2000, 12-15). Yrittäjätyyppien moninaisuudesta johtuen ei voida löytää yhtä persoonallisuusrakennetta, joka kuvaisi yrittäjää.

$\mathrm{K}$ aiken kaikkiaan yrittäjyyden määrittelyssä kieoutuvat toisiinsa monenlaiset persoonallisuudenpiirteet, vaatelias kyky oppia ja jatkuvasti kehittyä yhdistyneenä kykyyn havaita oikeita olosuhteita ja toimintaympäristöjä. Yllättävän vähäisesti yrittäjyyttä on tutkittu oppimisen näkökulmasta: minkä kaiken oppiminen ja millä tavalla oppiminen on välttämätöntä yrittäjänä menestymiseksi. Kirjallisuuskatsaus toi selkeästi esille, että yrittäjänä menestyminen on monien 
tekijöiden säätelemä, pitkäjänteinen prosessi, jossa oppiminen ja kehittyminen ovat avainasemassa. Kasvatustieteilijöiden ja kauppatieteilijöiden tutkimusyhteistyö yrittäjyyden oppimisprosessien selvittämiseksi olisi hedelmällistä.

Yrittäjyyden tutkiminen oppimisprosessina olisi mielekästä niin menestyneen kuin epäonnistuneenkin yritystoiminnan näkökulmasta. Virheistä oppimisen, riskien ottamisessa erehtymisen, väärien tuotteiden luomisen tai luottotappioiden kertymien analysoinnista on vähäisesti kasvatustieteellistä tutkimusta. On inhimillisesti ymmärrettävää, joskaan ei tieteen näkökulmasta suotavaa, että yrittäjä ei helposti antaudu tutkimuskohteeksi selvitettäessä liikeidean toimimattomuutta ja yrittäjyydessä epäonnistumista. Yrittäjyyteen saumattomasti liittyvä kilpailullisuus aiheuttaa myös sen, että niin menestyvien kuin epäonnistuvienkin toimintatapojen paljastaminen tutkimusmateriaaliksi on arveluttavaa tai liian "kallista", yrittäjällekin liian suuri riski.

$\mathrm{K}^{2}$ asvatustieteellisestä näkökulmasta on hedelällisempää tutkia yrittäjyyttä siihen sisältyvien oppimis- ja kehittymisprosessien kautta kuin persoonallisuuden analysoinnin avulla. Kirjallisuuskatsauksessa päädyimme siihen, että yrittäjäpersoonan erittely ei tuota mitään erityistä uutta näkökulmaa yrittäjyysilmiöön. Sen sijaan tilannetekijöitä, jotka vetävät tai työntävät yrittäjäksi, olisi mielekästä tutkia myös kasvatustieteellisestä näkökulmasta, koska kaikki yrittäjän ympärillä olevat tilanteet voidaan mieltää vaihtuvina ja vaikuttavina oppimisympäristöinä. Minkälaiset tilanteet yrittäjä tulkitsee oppimista ja kehittymistä mahdollistaviksi? Mitkä erityiset piirteet ympäristötekijöissä aktivoivat yrittäjää oppimaan ja kehittymään? Mikä estää yrittäjää oppimasta virheistään? Näihin kysymyksiin vastausten saaminen edellyttäisi yrittäjän käyttäytymisen ja motiivirakenteiden tutkimista kasvatustieteellisestä näkökulmasta. Huomattavan vähän on vielä tutkimusta siitä, millaiseksi oppijaksi yrittäjä itsensä kuvaa tai minkälaisilla opetusmenetelmillä tai -järjestelyillä voitaisiin yrittäjien reflektiivisyyttä oman oppimisensa ohjaajina aktivoida.

\section{Lähteet}

ALDRICH, H. \& Zimmer, C. (1986). Entrepreneurship through social networks. Teoksessa D.L. Sexton \& R.W. Smilor (toim.) The art and science of entrepreneurship. Ballinger, Cambridge, Mass.

BRUNSSON, N. (1989). The Irrational Organization. Irrationality as a Basis for Organizational Action and Change. John Wiley \& Sons, New York.

GARTNER, W. B. (1985). A Conceptual Framework for Describing the Phenomenon of New Venture Creation. Academy of Management Review 4, 696706

HUUSKONEN, V. (1992). Yrittäjäksi ryhtyminen. Teoreettinen viitekehys ja sen koettelu. Turun kauppakorkeakoulun julkaisuja sarja a-2.

JOKELA, P. \& Anneberg, M. (1995). Yrittäjyys. Ammatti ja tulevaisuus. WSOY.

JÄRVINEN, A. (1986). Miksi tänä päivänä puhutaan yrittäjyydestä? Yritystalous 1, 9-12.

KAST, F. \& Rosenzweig, J. (1970). Organization and Management. A Systems Approach. McGraw-Hill Inc, New York.

KETTUNEN, P. (1989). Yritys ja yhteiskunta. Gummerus Kirjapaino Oy, Jyväskylä.

KINKKI, S. (1992). Yritysavain. Yrityksen perustoiminnot. WSOY, Porvoo.

KOIRANEN, M. (1993). Ole yrittäjä. Ulkoinen ja sisäinen yrittäjyys. Tammer-Paino Oy, Tampere.

KOIRANEN, M. (1997). Henkinen kasvu yrittäjyyteen. Teoksessa Matti Parikka (toim.) Kasvu yrittäjyyteen. Jyväskylän yliopisto. Opettajankoulutuslaitos. Opetuksen perusteita ja käytänteitä $27,23-$ 26 .

KOIRANEN, M. \& Peltonen, M. (1995). Yrittäjyyskasvatus. Ajatuksia yrittäjyyteen oppimisesta. Tammer-Paino, Tampere.

KOIRANEN, M. \& Tuunanen, M. (1996). Asiakasyrittäjyys. Konetuumat $\mathrm{Oy}$.

LAHTI, A. (1989). Yrittäjyyden voima on rajaton. Yritystalous 4, 28-36.

LAITINEN, E. (1985). Keskisuomalaisen pienyrittäjän persoonallisuus. Teoksessa Pertti Kansanen 50 vuotta: Talous, yrittäjyys, laskentatoimi. KeskiSuomen taloudellinen tutkimuskeskus, Jyväskylä.

LAITINEN, E. (1986). Keskisuomalaisen yrittäjän persoonallisuus. Jyväskylän yliopiston täydennyskoulutuskeskuksen tutkimuksia ja selvityksiä 1 .

LEHTIPURO, K., Kangasaho, E. \& Niemelä, T. (1999). Uskalla sinäkin. Otava. Keuruu.

LITTUNEN, H. (1989). Aloittavien teollisuusyritysten menestystekijät. Jyväskylän yliopiston Keski-Suomen taloudellisen tutkimuskeskuksen julkaisuja 98 .

LITTUNEN, H. (1992). Uusien yritysten menestyminen. Tutkimuksen toteutustapa ja perustamistilanteen kartoitus. Keski-Suomen taloudellisen tutkimuskeskuksen julkaisuja 124. Jyväskylän yliopisto.

LORRAIN, J. \& Dussault, L. (1988). Relation Between Psychological Characteristics, Administrative Behaviors and Success of Founder Entrepreneurs at the Start-Up Stage. Teoksessa Kirchhoff Bruce A., Long Wayne A., McMullan W. Ed, Vesper Karl, H., Wetzel, William E. Jr. (toim.) Frontiers of Entrepreneursip Research 1988. Center for Entrepre- 


\section{KA T S A U K S I A}

neurial Studies, Babson College, Wellesley Massachusetts, USA, 150-164.

LOW, M. B. \& MacMillan, I.C. (1988). Entrepreneurship: Past Research ad Future Challenges. Journal of Management 2, 139-161.

MARCH, J. \& Olsen, J. (1979). Ambiguity and Choice in Organizations. (2 ed.) Universitetsforlaget. Bergen-Oslo-Tromsa.

MÄKINEN, V. (1977). Yrityksen perustaminen. Teoreettinen tarkastelu. Yrityksen taloustieteen ja yksityisoikeuden laitos. Julkaisuja A 10. Tampereen yliopisto.

NIITTYKANGAS, H. (1985). Kehitysalueavustusten vaikutukset. Jyväskylän yliopiston Keski-Suomen taloudellisen tutkimuskeskuksen julkaisuja 64.

NIITTYKANGAS, H. \& Tervo, H. (1994). Teollisuuspainotteinen kehittäminen harvaanasuttujen alueiden mahdollisuutena. Maaseudun uusi aika maaseutututkimuksen ja -politiikan aikakauslehti $1,47-59$.

NURMI, J-E. (1995). Tavoitteet, keinot ja illuusiot ihminen tulevaisuutensa tekijänä. Tiedepolitiikka 1, 1-12.

NURMI, K. E. (1999). Yrittäjäksi kasvamisen oppimisprosesseja postmodernissa yhteiskunnassa. Teoksessa Paula Kyrö, Kari E. Nurmi \& Tuulia Tikkanen (toim.) Yrittäjyyden askeleita yhteiskunnassa. Yliopistopaino, Helsinki, 28-45.

NÄSI, J. (1991). Strategic Thinking as Doctrine: Development of Focus Areas and New Insights. Teoksessa J. Näsi (toim.) Arenas of Strategic Thinking. Helsinki.
PALOJÄRVI, J. (1998). Pk-yrittäjän päätöksenteko. Psyko-sosiaalinen näkökulma. Johtamiskoulutuksen julkaisuja 7. Jyväskylän yliopisto. Täydennyskoulutuskeskus.

PARKKINEN, K. (1999). Yrittämisestä ammatti? Edita. Helsinki.

PELTONEN, M. (1986). Yrittäjyys. Otava, Keuruu.

PICKLE, H. \& Abrahamson, C. (1976). Small Business Management. Santa Barbara.

PITKÄNEN, S. \& Vesala, K. (1988). Yrittäjyysmotivaatio Kymen ja Vaasan lääneissä. Vertaileva tutkimus yrittäjyyteen ohjaavista tekijöistä. Tutkimusraportteja 9. Tuotantotalouden osasto. Lappeenrannan teknillinen korkeakoulu.

STANWORTH, M.J.K. \& Curran, J. (1981). Growth and the Small firm - an alternative view. Teoksessa Gorb Peter, Dowell Philip \& Wilson Peter (toim.) Small Business Perspectives. London, UK.

SUTINEN, M. (1994). Kaikki mitä olet halunnut tietää yritystoiminnasta mutta et ole tiennyt keneltä kysyä. Opas yrittäjille, yrityksen perustamista suunnitteleville sekä yrittäjätutkintoon valmistautuville. Suomen Graafiset Palvelut Oy Ltd, Kuopio.

TULKKI, H. \& Vakkuri, M. (1996). Suunta. Yrittäjäkurssi. Otava, Keuruu

TURUNEN, P. \& Niemelä, P. (1995). Yrittäjien kokema taloudellinen turvattomuus ja sen hallinta. Kansaneläkelaitos. Sosiaali- ja terveysturvan tutkimuksia 6. Kelan omatarvepaino, Helsinki.

VIRTANEN N. \& Keskinen S. (2000). Yrittäjän muotokuva. Turun aluetyöterveyslaitos, raportti 15 . 